Acta vet. scand. 1988, 29, 265-266.

Brief Communication

\title{
Cephenemyia Ulrichii Brauer 1862, in Swedish Moose
}

Larvae of Cephenemyia (Latreille 1818), the moose bot fly (Diptera; Oestridae) are parasites of the nose and pharynx in cervidae.

In Europe 4 species of Cephenemyia are reported, C. trompe (Modeer 1786) in reindeer (Rangifer tarandus tarandus L), C. stimulator (Clark 1815) in roe deer (Capreolus capreolus L), C. auribarbis (Meigen 1824) in red deer (Cervus elaphus $L$ ) and fallow deer (Dama dama L), and C. ulrichii, Brauer 1862, in moose (Alces alces L) (Zumpt 1965, Grunin 1966). Of these, C. trompe is known from northern Scandinavia (Zumpt 1965, Grunin 1966), C. stimulator is reported from Denmark (Christiansen 1935), and C. ulrichii from Finland (Frey 1914, Brander 1963, Mikkola et al. 1982). This is the first report on C. ulrichii larvae found in Sweden.

During the years 1979-1986 the presence of Cephenemyia larvae in moose has been recorded 11 times at the National Veterinary Institute (NVI). The infected animals all emanated from northern Sweden (Fig. 1). Both sexes and different ages were represented.

The number of larvae found varied between 1-16 but must not be regarded as the number actually present in the living animals, as the material was transported long distances. and was of a heterogeneous origin.

The larvae were killed in boiling water and preserved in $70 \%$ alcohol according to Zumpt (1965). They were examined and identified using a stereomicroscope and keys of Zumpt (1965) and Grunin (1966). All were found to be third instar larvae of C. ulrichii (Fig. 2).

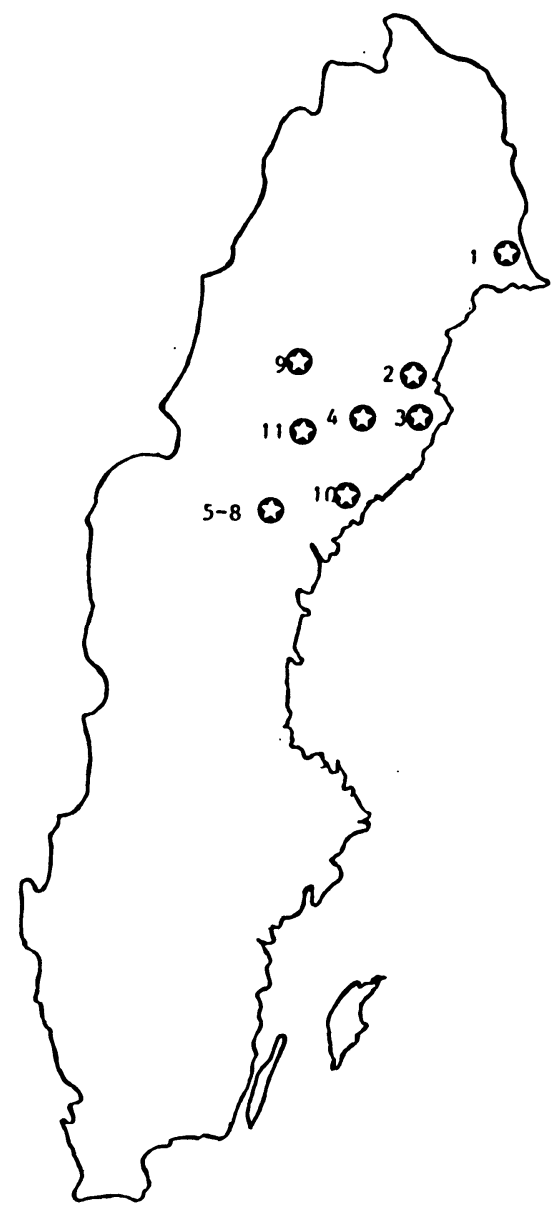

Figure 1. Localities of C. ulrichii infected moose in Sweden.

Case no. 1. Kullasjärvi (approx. $65.50^{\circ} \mathrm{N} 24.10^{\circ} \mathrm{E}$ ); 2. Kusmark (approx. $64.46^{\circ} \mathrm{N} 20.57^{\circ} \mathrm{E}$ ); 3. Hök-

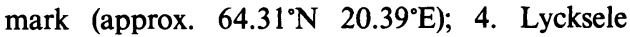
$\left(64.36^{\circ} \mathrm{N} \quad 18.40^{\circ} \mathrm{E}\right) ; \quad 5-8 . \quad$ Näsåker $\quad\left(63.26^{\circ} \mathrm{N}\right.$ $16.54^{\circ} \mathrm{E}$ ); 9. Gargnäs (approx. $65.30^{\circ} \mathrm{N} 17.30^{\circ} \mathrm{E}$ ); 10. Örnsköldsvik $\left(63.18^{\circ} \mathrm{N} 18.43^{\circ} \mathrm{E}\right)$; 11 . Åsele $\left(64.10^{\circ} \mathrm{N} 17.20^{\circ} \mathrm{E}\right)$. 


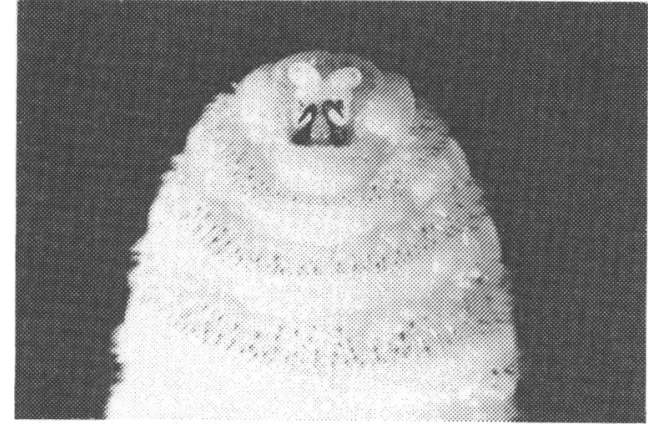

Figure 2. Cephenemyia ulrichii Brauer. Anterior ventral part of a third instar larva, viewing the antennal lobes and mouth hooks.

According to Zumpt (1965) the distribution area of this parasite in Scandinavia does not completely coincide with the distribution area of the host. Our report shows that C. ulrichii is distributed in a large area in northern Sweden which is, however, far from covering the total habitat area for moose in Sweden. Moose is found in the whole country except for the islands of Gotland and Öland.

The few reports on the parasite may depend on the fact that larvae of C. ulrichii are easily neglected during the hunting season (September-November) when they are about $3.5 \mathrm{~mm}$ long and most probably hidden in tonsil tissues as larvae of C. trompe in reindeer (Rehbinder \& Nordkvist 1983). Hence, all of our findings are from moose accidently killed during spring. The length of the third instar larvae is then around $40 \mathrm{~mm}$ and easy to discover.

A further examination of Scandinavian moose is needed to clarify the accurate distribution of the parasite and its effects on the host.

throat bot fly; Cephenemyia ulrichii; moose; Alces alces L; cervidae.

\section{Acknowledgements}

We are grateful to Dr. H. Andersson, University of Lund, Dr. A. Stark, Östervåla, for useful information and to Professor C. Rehbinder for constructive criticism.

Margaretha Stéen, Jan Chirico and

Dan Christensson,

National Veterinary Institute, Uppsala, Sweden.

\section{References}

Brander $T$ : havaintoja hirven nenäsaivartajasta suomessa. (Observations on Cephenemyia ulrichii in moose in Finland). Suomen Rista 1963, 16, 83-91.

Christiansen M: Raadyrets svælgbremse (Cephenomyia stimulator, Clark) i Danmark. (The roe deer noose bot fly (Cephenomyia stimulator, Clark) in Denmark. Maanedsskrift for Dyrlæger 1935, XLVI, 608-620.

Frey $R$ : Cephenomyia ulrichii Brauer, En på älg lefvande, för landet ny oestrid. (Cephenomyia ulrichii, Brauer, first findings of a new oestridae parasitizing moose). Medd. Soc. pro. Fauna Flora Fenn. 1914, 40, 117-119.

Grunin KJ: In: Die Fliegen der palaearktischen Region. (The flies of the palaearctic region). 1966, VIII, 64a, 1-97. E. Schweizerbartsche Verlagsbuchhandlung (Nägele u. Obermiller), Stuttgart.

Mikkola K, Silvennoinen J, Hackman W: Hirven nenäsaivartajan aiheuttama ihmisen oftalmomyiaasi. (Ophthalmomyiasis caused by the elk throat bot fly (Cephenemyia ulrichii) in man). Duodecim 1982, 98(13), 1022-1025.

Rehbinder C, Nordkvist M: Lokalisationen av svalgkormflugans (Cephenemyia trompe L) larver i svalget på en ren i en tidigare okänd tonsillvävnad (tonsilla pharyngis dorso-medialis). (The localization of the larvae of the nostril fly (Cephenemyia trompe L) in the pharynx of reindeer in an earlier unknown tonsil tissue). Rangifer 1983, 3(1), 46-49.

Zumpt $R$ : In: Myiasis in man and animals in the old world. Butterworths, London 1965, 146153.

(Received June 10, 1988).

Reprints may be requested from: Margaretha Stéen, National Veterinary Institute, P. O. Box 7073, S-750 07 Uppsala, Sweden. 